\title{
Celina Manzoni \\ Escritura de los límites: \\ hipérbole, exceso y dislocación de la escritura. A propósito de Insensatez de Horacio Castellanos Moya
}

En algún momento se conocía este secreto, que ahora, sin embargo, se ha olvidado: el mundo está compuesto por fragmentos que se desintegran, es un caos oscuro e inconexo sólo sostenido por la escritura.

Imre Kertész

\section{Errar/Escribir}

Los viajes, las migraciones, las diversas modalidades del exilio, las llamadas nuevas guerras y otros avatares de nuestra contemporaneidad han cuajado en la articulación de universos culturales atravesados por la perplejidad. Complejas operaciones de escritura transforman los lenguajes y la sintaxis de las narraciones para proponer nuevos relatos que, instalados a su vez en los difusos márgenes que convencionalmente delimitan espacios y géneros, transforman, entre otros imaginarios, las poéticas de la violencia.

En un ademán que superpone culturas, ciudades, lenguas, Guillermo Rosales publica en Miami un texto formidable en su desamparo y audacia: Boarding Home. Como en Final de un cuento de Reinaldo Arenas (1995), dos mundos se cruzan en la breve novela de Rosales, el de Miami y el de La Habana, con el resultado de que el protagonista se retira cantando bajito una canción de los Beatles: "He's a real nowhere man, sitting in his Nowhere Land" cuando no acierta a reconocer la propia imagen en las vidrieras espejadas de la ciudad (Manzoni 2006). Como en muchos otros textos publicados en la zona de pasaje de uno a otro siglo, los espacios, muchas veces urbanos, parecen constituirse en una compleja tensión entre aceptación y rechazo, cercanía y extrañamiento correlativa de la que desgarra a los personajes: "los lugares y los espacios, los lugares y los no lugares se entrelazan, se 
interpenetran. La posibilidad del no lugar no está nunca ausente de cualquier lugar que sea" (Augé 2005: 110).

Se tensan las contradicciones en torno a las grandes urbes: el D.F., una ciudad amada, apropiada y reapropiada en novelas tan diferentes entre sí como Y retiemble en sus centros la tierra de Gonzalo Celorio (1999) y Amuleto de Roberto Bolaño (1999); Medellín en La virgen de los sicarios de Fernando Vallejo (1994); La Habana en registros tan opuestos como Un arte de hacer ruinas de Antonio José Ponte (2005) y El rey de La Habana de Pedro Juan Gutiérrez (1999); Buenos Aires en La ciudad ausente de Ricardo Piglia (1992). Ciudades propias, apropiadas, nombradas una y otra vez en sus calles, sus rincones, sus edificios en ruinas o en la memoria de lo que fueron: todo parece apuntar a la conformación de una hermenéutica de la pérdida. En un esguince de ese juego de reconocimiento-desconocimiento, plenitud-falta, Insensatez de Horacio Castellanos Moya (2006) conforma, en cambio, una ciudad ajena, una ciudad que nunca se nombra pero sobre la cual flota, también ominosa, la sombra del desastre.

En las transformaciones de los lenguajes que sustenta esa casi desaforada creación de nuevos espacios urbanos y de nuevas estéticas, los quiebres de la lengua y de la memoria rearticulan el debate en torno a la construcción de identidades y proponen nuevos modos de narrar la violencia que, entre otros efectos, desmitifican los modelos urbanos de los sesenta en los brillantes textos de Guillermo Cabrera Infante, Carlos Fuentes o Vargas Llosa. Una violenta fragmentación afecta los modos de una imaginación errabunda que atraviesa no solo a los personajes de las novelas sino a los escritores. Así sucede también con Horacio Castellanos Moya, nacido en Honduras, hijo de padre salvadoreño, residente en El Salvador, México, Guatemala, Canadá, Estados Unidos, Alemania y otros países europeos que, puede decirse, parece realizar ejemplarmente una errancia que afecta a los protagonistas de sus narraciones y también al narrador de Insensatez.

Con sus libros, los de Arturo Arias, Dante Liano, Rodrigo Rey Rosa o Sergio Ramírez y con un renovado interés editorial tanto por la prosa como por la poesía de la región, después de décadas de violencia y de olvido, la literatura de esa estrecha franja de tierra entre el sur y el norte de América, ha vuelto a circular algo más allá de los límites de la ciudad letrada. Una literatura que en Guatemala se constituye en la manifestación más reciente de una compleja tradición que en el 
siglo XX pareció condensarse en la fama de Miguel Ángel Asturias, la universal admiración por Augusto Monterroso y por Luis Cardoza y Aragón, o, en otro registro, por el explosivo interés que provocó la más reciente tradición del testimonio inaugurada allí con el exitoso Me llamo Rigoberta Menchú y así me nació la conciencia (Burgos Debray 1983).

Los cruces de tradiciones entre una cultura mestiza ("ladina") y la intensa reivindicación de la cultura maya, objeto de renovado interés académico por parte de los llamados estudios subalternos, han sido motivo de análisis en términos altamente polémicos por Arturo Arias (2000) y por Mario Roberto Morales (2000). De ese modo, la inclusión de la literatura centroamericana en el mapa continental de las letras del siglo XXI, aunque todavía incompleta, propone algo más que una ampliación del registro; diluye el aura de invisibilidad de que había estado rodeado un imaginario poderoso que no puede menos que remitirse al Popol Vuh, un texto que en sus propias vicisitudes (destrucción, pérdida, ocultamiento, traducción, retraducción) parece constituirse en el epítome de una cultura poderosa afincada secularmente y al mismo tiempo fragmentada y hasta nómada.

\section{Borrar/Encubrir}

Aunque Insensatez apuesta por la ficción, como de manera ostensible destaca uno de los paratextos de la novela, no es posible evitar que la lectura se inserte en esa lábil frontera, esa como tierra de nadie en la que se demoran la ficción y la historia del presente. ${ }^{1}$ El narrador protagonista, extranjero en tierra ajena, propone desde la primera frase una inmersión en lo espantoso. Comprometido en la corrección de estilo de un informe sobre la violación de los derechos humanos en un país que no es el suyo, se sumerge en la perturbación, la duda y la desconfianza, y en ese complejo movimiento, mientras que por un lado ratifica la voluntad de cumplir con un contrato profesional cuyo

1 "Este es un libro de ficción. Nombres, personajes, lugares e incidentes son producto de la imaginación del autor o utilizados de manera ficticia. Cualquier parecido con personas reales, vivas o muertas, es una coincidencia" (Castellanos Moya 2005: 6). Una prevención que se podría vincular con la advertencia que preside a su vez una novela anterior de Castellanos Moya: El asco. Thomas Bernhard en San Salvador. 
carácter crematístico exhibe, por el otro pretende apartarse, cerrar los ojos, huir de lo que de manera forzosa se presenta a su mirada.

El texto surge del impacto que le provoca la "incursión en esas mil cien cuartillas impresas" (Castellanos Moya 2006: 13). Una tensión en cuyo vórtice construye una compleja estrategia narrativa que, en una primera flexión, se apoya en el encubrimiento de los nombres: de la ciudad y del país en el que se desarrolla la acción, de personas históricas -Rigoberta Menchú, monseñor Juan José Girardi, Carlos María Beristain, a veces reemplazados por las funciones que desempeñan, otras escondidos bajo nombres falsos. Una estrategia que al ocultar las referencias, problematiza los códigos de la representación y crea una atmósfera de secreto que involucra al mismo narrador, quien, amparado en la convención de la narración en primera persona, nubla su nombre así como nubla el nombre del destinatario o destinataria del libro: “A. S. D., quien me hizo prometerle que jamás le dedicaría este libro" (Castellanos Moya 2006: 9), dando cuenta de paso de la violación de un pacto de silencio. El gesto del encubrimiento, leído además en el contexto de la advertencia antes mencionada, más que proponer un juego de intriga y suspenso, que por lo demás logra, parece insinuar la peligrosidad de su revelación, algo que, mutatis mutandis, volvería justificable el clima persecutorio que atraviesa todo el relato.

La primera frase del libro, "Yo no estoy completo de la mente" (Castellanos Moya 2006: 13) (desglosada de un testimonio atribuido a un indígena cakchiquel sobreviviente del desastre y escrita en bastardilla) instala otro límite borroso, esa zona en la que parecen ponerse a prueba los frágiles bordes genéricos que separan el testimonio de la ficción. Surgida del estupor, desata, junto con la pasión coleccionista de frases, la paranoia del narrador, un delirio de persecución que lo convierte en un personaje intratable, violento y absurdo. Arrastrado y consumido por una forma o un grado de la locura en la que se siente inmerso, su violencia se sobreimprime a la violencia de los testimonios. Se van borrando los límites entre lo que lee y lo que escribe o reescribe, para constituir un texto en el que, superada la estética del testimonio tal como fue canonizada en los años setenta, las voces se le imponen con la fuerza de la gran poesía, ajena tanto a la compunción de las buenas conciencias como a la hipocresía de la corrección política. 


\section{Escribir/Injuriar}

Insensatez, lo mismo que El asco, una novela que suscitó encendidas polémicas y hasta amenazas de muerte para su autor, se sustenta en una estética que apuesta al uso de la diatriba, una figura retórica que se vincula con la injuria y con la imprecación, eventualmente con la ironía, y que en sus orígenes dio lugar con Bion (c.325-255 AC) a la diatriba cínica, finalmente una forma de discurso moral tal como se desprende de las definiciones del diccionario. ${ }^{2}$ Quizás haya que buscar en este uso proliferante de la diatriba la frecuente atribución de cinismo a la prosa de Castellanos Moya aunque, contradictoriamente, no se la diferencie del cinismo vulgar y se ignore su carácter subversivo cuando las formas del cinismo que se leen de manera oblicua en Insensatez se perfilan más bien como herederas de las originadas en el cinismo de Diógenes. Una actitud filosófica que, en palabras de Michel Onfray, propone "una gaya ciencia, un alegre saber insolente y una sabiduría práctica eficaz" y que remite a una definición clásica del cinismo debida a M. Goulet-Cazé:

Tras la causticidad de Diógenes y su intención de provocar, percibimos una actitud filosófica seria, tal como puede haber sido la de Sócrates. Si se dedicó a hacer caer una tras otra las máscaras de la vida civilizada y a oponer a la hipocresía en boga las costumbres del "perro", ello se debe a que Diógenes creía que podía proponer a los hombres un camino que los condujera a la felicidad (Onfray 2002: 32).

En la estela de la misma reflexión, además del sentido lúdico del cinismo, del humorismo que corroe a la doxa, me interesa su carácter ético sobre todo en sus relaciones con la estética, dicho esto en la sospecha de que la ética sería una modalidad del estilo, en el sentido de un estilo de vida pero también de un modo del arte que constituye nuevas formas de escritura a partir de una reconversión de retóricas probadamente eficaces. Las formas clásicas de la diatriba y de la injuria, propias de una moralidad cínica, se articularían en la prosa de Castellanos Moya como un modo de quebrar automatismos de género (novela, testimonio) y en ese sentido se las podría vincular con un amplio registro de la literatura latinoamericana que juega a la desesta-

2 Diatriba: "Discurso o escrito violento o injurioso contra personas o cosas" (RAE 2010); Injuria: "Agravio, ultraje de obra o de palabra. [...] Hecho o dicho contra razón y justicia. [...] Daño o incomodidad que causa una cosa. [...] menoscabo [...]" (RAE 2010). 
bilización de ritos escriturarios o que realiza un uso desestabilizador de recursos, estéticas y retóricas sea por proliferación, inversión o menoscabo, entre otros varios posibles procedimientos.

Si en "Arte de injuriar" Borges (1953: 150) destaca irónicamente como cualidad del género el "contrabando pertinaz de argumentos necesariamente confusos" mientras recupera su origen en "la tenebrosa raíz de la sátira" (Borges 1953: 151); si también se lo puede relacionar con formas más o menos sutiles del humor siempre entendido como crítica del poder, de cierta moralidad o simplemente de las supersticiones, un uso de la diatriba o de la injuria como exceso, al provocar, entre otros efectos, la risa sarcástica parece transgredir además los límites de las buenas costumbres y el gusto. En Insensatez además, el uso hiperbólico de la diatriba desata una desconfianza en los individuos pero sobre todo en las instituciones, todas las instituciones, aun aquellas que tradicionalmente parecen instaladas en el ilusorio espacio del bien absoluto.

Aunque su facundia se inhibe, casi se podría decir que se paraliza ante la muchacha torturada por Octavio Pérez Mena, el humor chocarrero desata como en cascada un machismo desaforado que se ensaña en las jóvenes españolas con las que el narrador fantasea. De todos modos, el blanco de sus diatribas, más que las personas, como en todo discurso moral, serán los vicios: para el caso, la corrección política, la hipocresía, la indiferencia vestida de bondad y compromiso, el oportunismo de la astuta conveniencia.

En el oprimente contexto de oscuridad y encubrimiento en que se desenvuelve la novela, la exaltada paranoia y la violencia de la injuria parecen sostener y agudizar un buscado efecto de distanciamiento al cuestionar la relación entre el mundo, el autor, el texto y el lector, pero, por sobre toda otra consideración, parecen funcionar como un contrapunto salvaje al horror y el miedo que desata la lectura de los testimonios.

La proliferación de la injuria como estética se constituye así, aunque pueda parecer contradictorio, en una estrategia que posibilita el avance de la narración. Como en Estrella distante de Roberto Bolaño (1996), Insensatez trata de responder a una pregunta que compromete la pulsión ética y la búsqueda artística: ¿Cómo narrar el horror? Si la formulación de la pregunta es más o menos la misma, la configuración de las respuestas es diversa. Castellanos Moya propone una articula- 
ción del texto a partir de las frases pronunciadas por hablantes cuya lengua materna no sería el español; en cualquier caso, esas frases resultan doblemente descoyuntadas, por su sintaxis sí pero también por la violencia a que se las somete al arrancarlas del texto original para incorporarlas a la clandestina libreta de apuntes del narrador que se va armando como un texto dentro del texto, un segundo libro, una verdadera puesta en abismo, un espacio de apropiación-reapropiación que involucra también al lector.

\section{Glosar/Traducir}

En el origen del libro existe un documento que recupera los informes de los sobrevivientes de 36 años de guerra civil en Guatemala (19601996) recogidos por una cadena de voluntarios: grupos de catequistas seguidos de los encargados de transcribir las cintas grabadas del maya al castellano, equipos de profesionales que clasificaron y analizaron los testimonios y redactaron el informe final. ${ }^{3}$ A partir de ese material Castellanos Moya realiza una serie de operaciones de escritura que pasa por una compleja apropiación y reapropiación de las frases de los testigos. En ese camino realiza movimientos vinculados en parte con la práctica de la glosa en el sentido de su acepción más corriente: "explicación o comentario de un texto oscuro o difícil de entender" (RAE 2010). Las formas de la glosa que despliega son diversas: en algunos casos parecen ceñirse a un comentario amplio acerca de los sentidos que se desprenden de una frase. "Yo no estoy completo de la mente", que como se ha dicho está en el origen del relato, desata el tono angustioso y precipitado de la reflexión acerca del impacto que provoca en el narrador, no solo porque supone en el hablante un grado de perturbación mental simultáneo a la conciencia del quiebre de la cordura, sino porque el motivo de ese trastorno hace extensiva la locura a la totalidad de los habitantes de un país en el que ese horror pudo suceder, a quienes elaboraron el informe y al propio narrador que concluye: "Yo tengo que estar mucho menos completo de la mente que estos sujetos" (Castellanos Moya 2005: 15).

3 Carlos María Beristain fue el coordinador del Informe REMHI (Proyecto de Reconstrucción de la Memoria Histórica de Guatemala), presentado públicamente el 24 de abril de 1998 por monseñor Juan José Girardi quien fue asesinado dos días después. 
El concepto de glosa como comentario autorizaría, por lo demás, su ampliación al ejercicio de la traducción, lo que Borges denominó las traslaciones literarias, un gesto que realizó de manera notoria en sus ensayos y en su propia práctica y que lo llevó a suponer que existen dos tipos de traducciones: la literal y la que practica la perífrasis; una y otra se corresponderían con dos tipos de mentalidades: la romántica que reverencia al individuo y justifica la literalidad y la clásica que aprovecha los repertorios de la propia lengua al verter un original. A partir de esos parámetros, así como de la posibilidad de traducir en el interior de una misma lengua, imagina dos versiones de los primeros versos del Martín Fierro: "Aquí me pongo a cantar/ al compás de la vigüela" (Hernández 1990: 111). Aunque ambas resultan ridículas, la broma subraya los lazos entre la traducción y la creación literaria y hasta cierto punto, su apuesta por la perífrasis. Reconoce sin embargo, que una traducción podrá parecer más pobre que su original:

También los versos de Evaristo Carriego parecerán más pobres al ser escuchados por un chileno que al ser escuchados por mí, que les maliciaré las tardecitas orilleras, los tipos y hasta pormenores de paisaje no registrados en ellos, pero latentes [...]. Es decir, a un forastero no le parecerán más pobres; serán más pobres. Su caudal representativo será menor (Borges 1997: 256).

La necesidad retórica de explicar una escritura y de explicar a los sujetos que intervienen en ella colocaría al narrador, como al traductor, ante una serie de opciones interpretativas, lo que Borges denominó: "un largo sorteo experimental de omisiones y de énfasis" (Borges 1964: 105). Ese proceso de traducción dentro del mismo código no solo constituye, como la glosa, una escritura siempre preocupada por explicar y explicarse, sino también un narrador en continuo desplazamiento lingüístico para asegurar un verosímil que, en este texto, de manera constante intenta ser negado por meramente insoportable.

Otra variante de la glosa en Insensatez evoca un ejercicio de estilo o más bien de crítica literaria: las frases que lee en el transcurso de su primer día de trabajo, no solo "parecían cápsulas concentradas de dolor [sino que] tenían tal sonoridad, fuerza y profundidad que yo había apuntado ya algunas de ellas en mi libreta personal" (Castellanos Moya 2005: 30). El entusiasmo por la intensidad de esas expresiones lo lleva a prodigarlas entre sus interlocutores quienes, por regla casi general, quedan al margen del impacto que conmueve al narrador. La 
fuerza de la palabra lo conduce a insistir ante su único amigo, el compadre Toto: se propone

mostrarle la riqueza de lenguaje de sus mal llamados compatriotas aborígenes, y ninguna otra cosa más, suponiendo que él como poeta hubiera podido estar interesado en ello, en esas intensas figuras de lenguaje y en la curiosa construcción sintáctica que me recordaba a poetas como el peruano César Vallejo (Castellanos Moya 2005: 32).

No consigue transmitir su entusiasmo, apenas logra arrancarle un comentario displicente sobre la frase: "Porque para mi el dolor es no enterrarlo yo..." (Castellanos Moya 2005: 32) que el amigo interpreta o traduce refiriéndola al conceptismo: "'Sólo ya el no querer es lo que quiero', recitó mi compadre, con un rictus de burla, [...] y después dijo: 'Quevedo"' (Castellanos Moya 2005: 33).

El conjunto de esos procedimientos: glosa, crítica, traducción y asimilación va realizando en la inestabilidad del lenguaje una forma de violencia que revierte sobre la violencia de lo narrado al acentuar la condición fragmentaria y frágil del discurso. En esa misma estética del traslado y la transformación podría ser enmarcada la fuerte apuesta que pasa por la subversión de los usos beatíficos del testimonio; en lugar de la supuesta transparencia atribuida al género, juega a borrar y encubrir, un modo de sostener, como se ha dicho, el clima persecutorio que atraviesa todo el relato y de proyectar los peligros implícitos en la exacerbación de una escritura hiperbólica, excesiva y paranoica. Si se partía del supuesto de que la estética del testimonio se sostenía en la ética del intelectual solidario que otorgaba voz a quienes no la tienen, el gesto de Castellanos Moya opera en un sentido diametralmente opuesto: el narrador no 'se hace solidario' con el terror de los testigos sino que recupera el miedo del otro, participa de su locura y de la desconfianza y, para decirlo, se apropia de las frases que lo expresan: "hay momentos en que tengo ese miedo y hasta me pongo a gritar" (Castellanos Moya 2005: 129).

\section{Escribir/reescribir}

Si las frases descoyuntadas desquician al narrador, su misma fuerza expresiva afila el ademán anticonformista; entusiasmado con la autocelebrada función de crítico literario se sorprende por el uso de la repetición y del adverbio en uno de los testimonios: en la frase "Lo 
que pienso es que pienso yo" (Castellanos Moya 2005: 43), lo atrapa un tipo de musicalidad

cuya calidad poética era demasiada como para no sospechar que procedía de un gran poeta y no de una anciana indígena que con ese verso finalizaba un desgarrador testimonio que ahora no viene al caso (Castellanos Moya 2005: 44).

También puede reaccionar con ferocidad cuando lee en las paredes de un bar "propiedad de comunistas reciclados" (Castellanos Moya 2005: 41) versos horribles de "mediocres poetas izquierdistas vendedores de esperanza" (Castellanos Moya 2005: 41). Frente a esos poemas penosamente bienintencionados cuya gastada sensiblería rechaza, recupera la poesía de las frases indígenas y la gran poesía política de César Vallejo: su gesto poético en España, aparta de mí este cáliz cuando supo provocar la intensificación interpretativa con una estética del asombro asentada en un quiebre de la norma:

\section{III}

Solía escribir con su dedo grande en el aire:

" Viban los compañeros! Pedro Rojas",

de Miranda de Ebro, padre y hombre,

marido y hombre, ferroviario y hombre,

padre y más hombre. Pedro y sus dos muertes.

Papel de viento, lo han matado: ipasa!

Pluma de carne, lo han matado: ipasa!

“¡Abisa a todos los compañeros pronto!” [...] (Vallejo 1992: 63).

Una escritura que remite de pronto también a una provocativa reflexión de Guillermo Cabrera Infante, quizás tempranamente instalada en las polémicas de los años sesenta en Cuba, en el cierre de su libro de relatos Así en la paz como en la guerra (1960). La mirada del narrador se detiene en las paredes de una cárcel batistiana, las manchas, la mugre y los mensajes truncos de los prisioneros:

'maMá tE Quiero mucHo PRUdeNcio' [...] Aparece otro: 'Biva, Cuva Lire!!!'. [...] Hay un dibujo obsceno y una palabra encima, terrible: 'Batista'. Otro ha querido describir las torturas y ha hecho un garabato.

Si hubiera más luz se podrían leer los demás mensajes. Pero los que hay bastan. Ellos son la verdadera literatura revolucionaria (Cabrera Infante 1960: 200-201).

En un contexto diverso también atravesado por la violencia del Estado contra los ciudadanos, Dos veces junio de Martín Kohan (2005) apela a un cuaderno de notas: "Había una sola frase escrita en esas dos pá- 
ginas que quedaban a la vista: Decía: ‘¿A partir de qué edad se puede empesar a torturar a un niño?"' (Kohan 2005: 11). La brutalidad de la pregunta que abre esta novela se expande con el error ortográfico por el cual la "z" del infinitivo es reemplazada por una "s". Desde ese narrador, alguien a quien perturba la violación de la ortografía pero no el horror que la pregunta encierra, todo el texto se constituye como una estrategia dirigida a la reflexión sobre lo que parece resistirse a la racionalidad.

La apropiación estética de una sintaxis y de una ortografía descentrada o excéntrica -respecto de un centro del que se margina- produce una fractura, un efecto de momentánea suspensión en la percepción del lector, el asombro que al operar sobre la violación de los códigos de la lengua intensifica y resignifica la escritura. Con la copia en su libreta de apuntes de las frases que lo sorprenden, el narrador de Insensatez reescribe y traslada, metafóricamente, traduce la violencia de los códigos sociales. La libreta de apuntes se constituye así en una inversión o quizás en una parodia de la libreta de apuntes de los naturalistas; mientras Émile Zola y sus discípulos anotaban hechos que sometían a la observación y la experiencia para evitar el misterio de influencias desconocidas o que escapaban a las leyes de la naturaleza -lo que el maestro denominó el método experimental- este narrador anota la palabra de los sobrevivientes y a partir de esa subjetividad construye un texto.

Si el gesto de recuperar para la lectura y relectura en soledad "aquellas frases que me parecían estupendas literariamente" (Castellanos Moya 2005: 43) es presentado cínicamente como un modo de satisfacción personal: "con suerte [las] podría utilizar posteriormente en algún tipo de collage literario" (Castellanos Moya 2005: 43), el choque con la insensibilidad de sus interlocutores o el temor de que sea descubierta la infidencia de la libreta de apuntes refrena su entusiasmo. No obstante, ni disfrute en soledad ni pieza de museo; alaba una vez más "un texto preciso en el análisis y con unos testimonios conmovedores, alucinantes, en especial ese lenguaje de una riqueza expresiva digna de la mejor literatura" (Castellanos Moya 2005: 68). Ante una experiencia que en muchos sentidos lo supera, esas frases serán su amuleto, llegarán a ser no solo salvaguarda del miedo, sino descripción de su propio estado de ánimo: “ipero yo siempre me sien- 
to muy cansado de que no puedo hacer nada!" (Castellanos Moya 2005: 113).

Otra inflexión del ademán que enlaza escritura y reescritura parece encontrar su propio límite en un episodio desplegado en la mitad del libro (capítulo seis) en el que recupera la historia de un funcionario indígena encargado de llevar el registro escrito de los muertos de la aldea (la memoria de su pueblo). Porque se resiste a entregar el documento al ejército, antes de ser asesinado, sufre la mutilación de las manos. La lectura de ese testimonio, verdadero centro productor de la escritura de la novela que leemos, desata en el narrador la voluntad o el deseo de la escritura propia, imagina que podría escribir una novela aunque dice saber que: "en realidad no había tal novela sino las ganas de hacerla, de trastornar la tragedia, de convertirme en el alma en pena del registrador civil de un pueblo llamado Totonicapán" (Castellanos Moya 2005: 71-72). Imagina un posible comienzo y una trama imposible de suspenso y aventuras en la que no falta una referencia irónica a la estética del realismo mágico pero en la que se privilegia una identificación, un deseo de escritura que discursivamente se frustra: la escritura de la novela que hubiera sido posible "si yo hubiera sido entonces un novelista, claro está, y no el corrector de barbaridades que soñaba con ser quien no era" (Castellanos Moya 2005: 74).

Como consecuencia de todos estos procedimientos se difuminan los límites, en particular los que podrían llegar a establecerse entre una definición rutinaria de ficción y una definición clásica y altamente ideologizada de testimonio; al eludir las trampas de la sentimentalidad bienpensante, un narrador en las antípodas de la corrección política se apropia y reapropia de las voces no con la pretensión de hablar en su nombre; son los miembros de las comunidades quienes hablan, voces de víctimas pero voces reflexivas que, desplazadas del cuerpo del informe, restallan en el libro. Como en el vanguardista operativo de traslado realizado por Marcel Duchamp, en su desplazamiento de un espacio normativizado como el del informe al espacio literario alcanzan una identidad literaria que las hace únicas e irrepetibles. 


\section{El otro/el mismo}

La identificación del narrador con las voces y el miedo de los sobrevivientes convoca un exaltado y fulminante delirio persecutorio:

[...] al borde del trastorno, luego de darme cuenta de que me encontraba tan incompleto de la mente que había aceptado y estaba iniciando un trabajo con los curas que ya me habría puesto en la mira de los militares (Castellanos Moya 2005: 16).

En todo ve los signos de una conspiración; la imagen que va ofreciendo de sí mismo se confunde con la de un individuo desorbitado y presa del pánico que vive cada minuto como un desafío contra emboscadas, crímenes y persecuciones. La hipérbole, el exceso y la paranoia en contrapunto con una cotidianidad en apariencia normal, exacerban la violencia de la escritura. El brindis supuestamente tranquilizador de su amigo: "por que salgás vivo de esa mierda" (Castellanos Moya 2005: 24), como su desenfadada desestimación de las sospechas, más bien las corrobora: "Dejate de culeadas, cuando los chafas te quieran enviar un mensaje, mínimo te van a pegar un trabón" (Castellanos Moya 2005: 64).

En esa tensión y a medida que el narrador avanza en el alucinante proceso de lectura/escritura/reescritura de las frases, el nombre sin rostro de Octavio Pérez Mena, el teniente torturador que luego ascendido a general se convertirá en el Jefe de Inteligencia del Ejército, se volverá casi omnipresente en la segunda parte del libro cuando en un instante de terror intuye que es el tercer personaje de una reunión secreta entre su empleador del Arzobispado y un antropólogo forense. Basa su caprichoso reconocimiento en tres rasgos arquetípicos: el porte militar, la mueca rígida y "esa mirada de cobra a punto de atacar" (Castellanos Moya 2005: 128), imagen que no tarda en relacionar con una de las frases que atesora: "al principio quise haber sido una culebra venenosa, pero ahora lo que pido es el arrepentimiento de ellos" (Castellanos Moya 2005: 135-136). El habitual procedimiento de la glosa y la transformación trabaja aquí por acumulación de sentidos en torno a la venganza y los modos imaginarios de la venganza por parte de un indígena para, en un movimiento circular, invertir al sujeto de la venganza y volver a "la jeta de culebra venenosa que tenía el general Octavio Pérez Mena" (Castellanos Moya 2005: 136) y con ella a un miedo que lo paraliza y lo confina en el encierro. 
Ya casi en el límite de la perturbación, una imagen que se repetía en los informes

me fue penetrando hasta poseerme [...] como si yo fuese ese teniente que irrumpía brutalmente en la choza de la familia indígena, tomaba con mi férrea mano al bebé de pocos meses por los tobillos, lo alzaba en vilo y luego lo hacía rotar por los aires, cada vez a más velocidad, como si fuese la honda de David (Castellanos Moya 2005: 137).

Cuando "mi mente se me fue de las manos" (Castellanos Moya 2005: 139), culminación de todas las vueltas que le dio a la frase inaugural del libro, "yo no estoy completo de mi mente", el narrador se desdobla; transformado en el teniente Octavio Pérez Mena, fuera de sí (nunca se dijo mejor "fuera de sí"), deambula desesperado y sale al parque a aullar: un modo del desdoblamiento que recupera algunas de las formas literarias que se han vuelto clásicas en la literatura del doble estudiadas por Otto Rank y Sigmund Freud. También lo que Bercovitch denominó una "'automachia', a battle of the self against the self" (Folkenflik 1993: 216).

La transformación en el doble siniestro, como si

fuera la catarsis que me liberaba del dolor acumulado en las mil cien cuartillas en las que enseguida me volvía a sumir, en un ciclo repetitivo de concentración prolongada con intervalos para la misma fantasía macabra (Castellanos Moya 2005: 138-139),

se constituye en el límite de un lector perturbado. Miedo del otro, miedo de sí mismo, no se permite dar batalla y solo le queda la huída, cualquier otra estrategia sería una insensatez.

Finalmente, en el cierre y desde otro espacio, el texto parece proponer un cambio de tono. El narrador, con cierta ecuanimidad, imagina ahora su aventura como la de un cometa que ha rozado a la tierra de manera esporádica: "La Tierra no quiere saber nada ni entiende lo que le cuenta el cometa, pues ella está feliz en su órbita y odia ser perturbada por quien solo aparece de vez en cuando y quién sabe de dónde" (Castellanos Moya 2005: 147). Apoyado en la barra de un bar una noche de carnaval en Alemania, racionaliza: su fugaz intervención solo habría servido para perturbar un ritmo aceptado por todos, inclusive por algunos testigos indígenas ("que se borre el nombre de los muertos para que queden libres y ya no tengamos problemas", Castellanos Moya 2005: 144). Sin embargo, de pronto no se reconoce en el espejo: "mi expresión [...] se me hizo ajena, como si el que estaba ahí 
no hubiera sido yo, como si ese rostro por un instante hubiera sido de otro, de un desconocido, y no mi rostro de todos los días" (Castellanos Moya 2005: 147). Vuelven el pánico, el miedo a la locura, la obsesión por la libreta de apuntes y las frases que conoce de memoria: "Para mí recordar, siento yo que estoy viviendo otra vez" (Castellanos Moya 2005: 149). Una frase

cuya sintaxis cortada era la constatación de que algo se había quebrado en la psiquis del sobreviviente que la había pronunciado, una frase que cabalmente se aplicaba a mi situación en esa ciudad extranjera [...] donde para mí recordar era vivir otra vez los testimonios de pesadilla tantas veces leídos (Castellanos Moya 2005: 149).

$\mathrm{Si}$ escribir es escribirse, la ajenidad del propio rostro en la escena del espejo, su extrañamiento es indicio de una identidad quebrada que con temor busca conjurar la peligrosidad del doble y por un juego de asociaciones recupera una frase: "eran personas como nosotros a las que teníamos miedo" (Castellanos Moya 2005: 150). La repite tres veces en un tono cada vez más alterado; cercado por una lengua que desconoce habla solo y, eludiendo el espejo, vuelve a la libreta de apuntes, de nuevo disfruta de las frases, las repite en voz alta, recupera su música y con ellas las emociones. Ya inmerso en aquello de lo que huyó se pregunta si habrán aceptado el título que propuso para el informe que en esos días se presentará: "Todos sabemos quiénes son los asesinos" (Castellanos Moya 2005: 153); es cuando al repetir la frase en voz alta descubre que a su derecha de la barra está sentado el general Octavio Pérez Mena y lo provoca a un brindis: "Todos sabemos quiénes son los asesinos" (Castellanos Moya 2005: 154). El otro rehúsa como quien no entiende la lengua en la que le hablan, un subterfugio, según la lógica paranoica del narrador que lo desafía: "Después vivimos el tiempo de la zozobra" (Castellanos Moya 2005: 154). De nuevo un exceso persecutorio que se resignifica cuando conocemos de manera casi simultánea que el informe ha sido presentado y que monseñor ha sido asesinado.

La propuesta de utilizar la frase de una anciana indígena como lápida de los huesos desenterrados: "Que siempre los sueños allí están todavía" (Castellanos Moya 2005: 122),

esa espléndida frase que había iluminado mi tarde de trabajo en el palacio arzobispal con su sonoridad, su estructura impecable abriéndose a la 
eternidad sin soltar el instante, con ese uso del adverbio que retorcía el pescuezo del tiempo (Castellanos Moya 2005: 122),

realiza en otra inflexión, el drama de las tumbas sin nombre. Recupera la importancia que tuvo la sepultura en los más antiguos sistemas de pensamiento: "el que carece de tumba carece hasta de la oscura inmortalidad de la especie", dice María Rosa Lida (1944: 37-38) comentando la Antígona de Sófocles, obra en la que el entierro de los restos de Polinices ha pasado de la posición episódica que ocupara en las obras de Eurípides a una posición esencial. Tan fundamental es ese texto clásico en un contexto de guerra civil, que el epígrafe de Insensatez reproduce las palabras con que Ismene justifica a Antígona abatida por la fuerza del Estado. Contra la razón de Estado, la razón de Antígona: "Con todo, Hades, al menos dispone idénticas leyes para uno y otro" (Sófocles 1987: verso 519); un saber reputado de insensatez y locura por Creonte, es defendido por Ismene: "Nunca, señor, perdura la sensatez en los que son desgraciados, ni siquiera la que nace con ellos, sino que se retira" (Sófocles 1987: versos 563-565). Una lápida para los huesos desenterrados con la esperanza de que el tiempo de la zozobra pueda expresarse 'en poesía de la mejor', como si una vez más lo único que pudiera sostener el mundo fuera la escritura.

\section{Bibliografía}

Arenas, Reinaldo ([1982] 1995): "Final de un cuento". En: Arenas, Reinaldo: Adiós a mamá. De La Habana a Nueva York. Barcelona: Áltera, pp. 147-175.

Arias, Arturo (2000): "Después de la guerra centroamericana: identidades simuladas, culturas reciclables". En: Moraña, Mabel (ed.): Nuevas perspectivas desde/sobre América Latina. El desafio de los estudios culturales. Santiago de Chile: Cuarto Propio - Instituto Internacional de Literatura Iberoamericana, pp. 429-446.

Augé, Marc ([1992] 2005): Los no lugares. Espacios del anonimato. Una antropología de la sobremodernidad. Barcelona: Gedisa.

Bolaño, Roberto (1996): Estrella distante. Barcelona: Anagrama.

- (1999): Amuleto. Barcelona: Anagrama.

Borges, Jorge Luis ([1933] 1953): “Arte de injuriar”. En: Borges, Jorge Luis: Historia de la eternidad. Buenos Aires: Emecé, pp. 145-155.

- ([1932] 1964): "Las versiones homéricas". En: Borges, Jorge Luis: Discusión. Buenos Aires: Emecé, pp. 105-112.

- ([1926] 1997): "Las dos maneras de traducir”. En: Borges, Jorge Luis: Textos recobrados. 1919-1929. Buenos Aires: Emecé, pp. 256-259. 
Burgos Debray, Elizabeth (1983): Me llamo Rigoberta Menchú y así me nació la conciencia. La Habana: Casa de las Américas.

Cabrera Infante, Guillermo (1960): Asi en la paz como en la guerra. La Habana: Ediciones R.

Castellanos Moya, Horacio (2005): Insensatez. Barcelona: Tusquets.

- ([1997] 2006): El asco. Thomas Bernhard en San Salvador. San Salvador: Arcoiris.

Celorio, Gonzalo (1999): Y retiemble en sus centros la tierra. Barcelona: Tusquets.

Folkenflik, Robert (1993): "The Self as Other". En: Folkenflik, Robert (ed.): The Culture of Autobiography. Constructions of Self-Representation. Stanford: Stanford University Press, pp. 215-234.

Gutiérrez, Pedro Juan (1999): El rey de La Habana. Barcelona: Anagrama.

Hernández, José (1990): Martín Fierro. Madrid: Cátedra.

Kertész, Imre ([2003] 2005): Liquidación. Madrid: Punto de Lectura.

Kohan, Martín ([2002] 2005): Dos veces junio. Buenos Aires: Debolsillo.

Lida, María Rosa (1944): Introducción al teatro de Sófocles. Buenos Aires: Losada.

Manzoni, Celina (2006): "Traducciones y traslados. A propósito de Boarding Home de Guillermo Rosales". En: Jitrik, Noé (ed.): Aventuras de la crítica. Escrituras latinoamericanas en el siglo XXI. Córdoba: Alción, pp. 285-292.

Morales, Mario Roberto (2000): "La articulación de las diferencias: el discurso literario y político del debate interétnico en Guatemala". En: Moraña, Mabel (ed.): Nuevas perspectivas desde/sobre América Latina. El desafio de los estudios culturales. Santiago: Cuarto Propio/Instituto Internacional de Literatura Iberoamericana, pp. 447-452.

Onfray, Michel ([1990] 2002): Cinismos. Retratos de los filósofos llamados perros. Buenos Aires/Barcelona/México, D.F.: Paidós.

Piglia, Ricardo (1992): La ciudad ausente. Buenos Aires: Sudamericana.

Ponte, Antonio José ([2000] 2005): Un arte de hacer ruinas y otros cuentos. Ed. de Esther Whitfield (prólogo, bibliografía y notas). México, D.F.: Fondo de Cultura Económica.

RAE (Real Academia Española) (222010): Diccionario de la Lengua Española. Vigésima tercera edición en internet: <www.buscon.rae.es/draeI/> (30.11.2010).

Rosales, Guillermo ([1987] 2003): La casa de los náufragos. Boarding Home. Madrid: Siruela.

Sófocles (1987): Antígona. Introducción, notas y traducción de Leandro Pinkler y Alejandro Vigo. Buenos Aires: Biblos.

Vallejo, César ([1937] 1992): España, aparta de mí este cáliz. Madrid: Ediciones de la Torre.

Vallejo, Fernando (1994): La Virgen de los sicarios. Santafé de Bogotá: Alfaguara. 